\title{
SEVERE PNEUMONIA CAUSED BY ANTIPSIHOTIC DRUGS - WHAT DOES NOT SUIT, THE PATIENT OR THE DRUG?
}

\author{
Lazovic Biljana, ${ }^{1}$ Blazic Ivana, ${ }^{1}$ Zlatkovic-Svenda Mirjana, ${ }^{2,4}$ Zugic Vladimir ${ }^{3,4}$ \\ ${ }^{1}$ University clinical center "Zemun", Belgrade, Serbia \\ ${ }^{2}$ Institute of rheumatology, University of Belgrade, Belgrade, Serbia \\ ${ }^{3}$ Clinic for lung diseases, Clinical center of Serbia, Belgrade, Serbia \\ ${ }^{4}$ School of medicine, University of Belgrade, Serbia
}

Primljen/Received 13. 08. 2018. god.

Abstract: Introduction: Antipsychotic drugs are generally categorized as typical antipsychotics (sometimes referred to as first-generation or conventional antipsychotics, or neuroleptics) and atypical antipsychotics; both are approved for the treatment of acute and chronic psychoses (i.e, schizophrenia), mania, agitation, and other psychiatric disorders. In 2005 the US Food and Drug Administration issued a warning about the increased risk of all-cause mortality associated with atypical antipsychotic use in elderly patients with dementia. Community acquired pneumonia (CAP) was one of the most frequently reported causes of death. The same warning was extended to typical antipsychotics in 2008 with extension to people with or without dementia.

Case report: We present a 65-year-old Caucasian woman who was admitted to hospital due to massive pneumonia. She was suffered forschisophrenia 15 -years and at moment of admission she was in remission. She had continuously high fever up to 40 degrees. All collected cultures (blood, sputum, urine, smear of aspirating catheter) were negative. She was treated with various antibiotics without improvement. After changing antipsychotic drugs, she showed slow improvement until total recovery after 3 months.

Discussion and conclusion: Antipsychotic-associated CAP seems to be a clinically relevant issue in frail elderly patients, as consistently documented in several epidemiologic investigations. No clear evidence exists for an increased risk of pneumonia in younger patients treated with antipsychotics. In elderly populations, the increase in risk is dose-dependent, and is more pronounced in the early phases of treatment. Future studies should better define the mechanism underlying antipsychotic-induced pneumonia and identify subgro-
Prihvaćen/Accepted 13. 09. 2018. god.

ups of antipsychotic users at higher risk of developing pneumonia.

Key words: antipsihotic drugs, schizophrenia, pneumonia, drug toxicity.

\section{INTRODUCTION}

Antipsychotics, indicated for acute and chronic psychosis and other psychiatric disorders treatment, are generally distinguished as atypical and typical agents (1). Because pneumonia isone of the most frequently reported death causes in olderpatients, several observational studies have evaluated the association between antipsychotic usage and the risk of fatal/nonfatal community-acquired pneumonia (CAP) recently (2).

\section{CASE REPORT}

A 65-year-old Caucasian woman was presented to the Emergency Department, complaining of a 3-day continuous high fever up to 40 degrees associated with a productive cough. The patient had a 15 -years schisophrenia history and has achieved full remissionfor two last years, but becauseof new onset of anxiety, psychiatrists changed therapy to Risperidone $2 \mathrm{mg}$ daily, Mirtazapine $15 \mathrm{mg}$ daily, Carbamezepine $200 \mathrm{mg}$ daily and Parohetine $20 \mathrm{mg}$ daily usage, a week before admition to hospital. Her last therapy was clozapine, when she achieved remission for two years. At the Emergency Department, the patient was febrile- 39C, generally weak and with a depressive mood. Her blood pressure was $95 / 65 \mathrm{~mm} \mathrm{Hg}$, while her pulse was 110 beats per minute and regular. Chest examination revealed dullness on the upper right lobe; other breath and heart sounds were normal. There were no signs of hepato- 


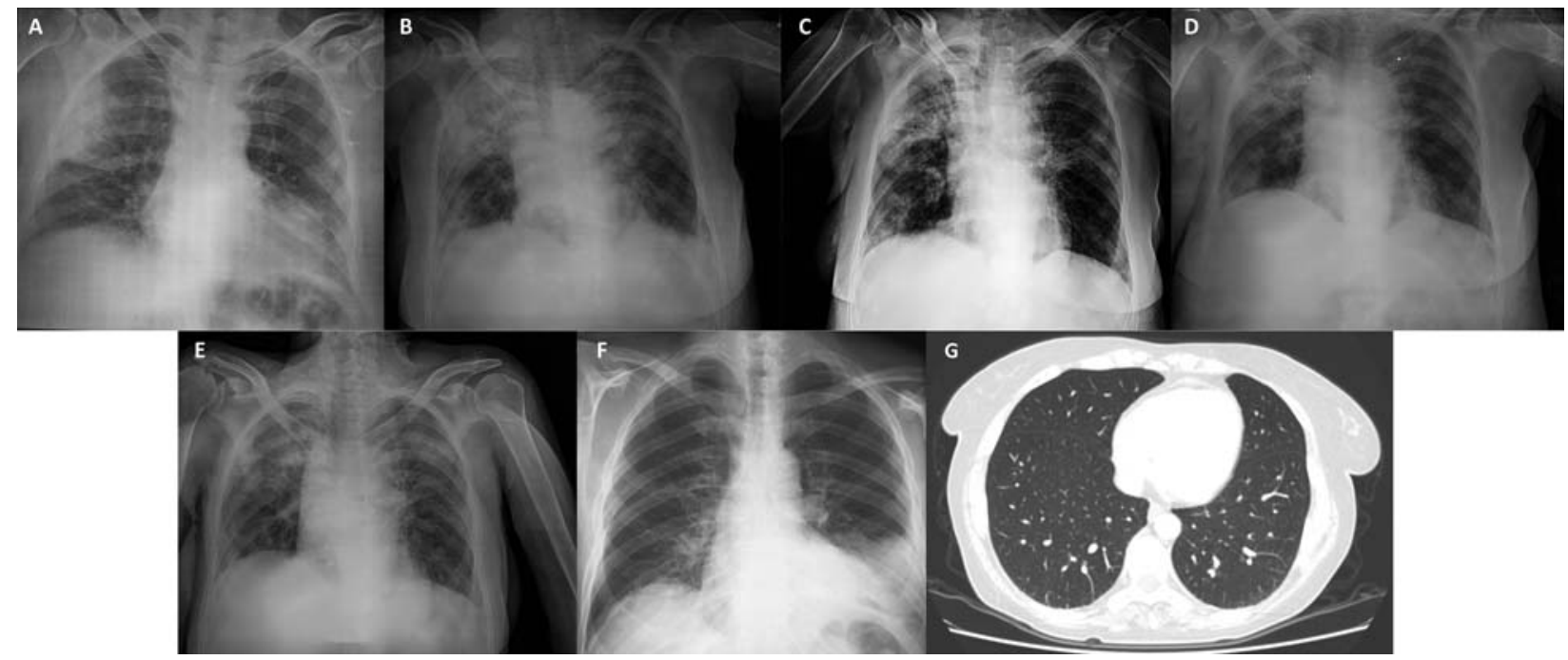

Figure 1. Chest $X$ ray of the antipsychotic-drugs induced severe pneumonia patient

$\boldsymbol{A}$-on admitting; $\boldsymbol{B}$-Chest $X$ ray taken after initiation of antibiotics (ceftriaxone and ciprofloxacin) three days after; $\boldsymbol{C}$-After 3 days of initiation of Vankogal, Metronidazole and Amikacin-showing no improvement;

D-Atthird dayafter initiation of Levofloxacin and Metronidazole and reducing antipsychotic drugs dosage; $\boldsymbol{E}$-Little regression of inflammation and start with Colistin; $\boldsymbol{F}$-Significant radiological regression of inflammatory process after one month from treatment induction; $\boldsymbol{G}$ - complete resolution of inflammatory process after 3 weeks from last chest $X$ ray

splenomegaly, lymphadenopathy, abdominal tenderness and pathological abdominal masses. The chest radiogram has shown the right-sided upper pneumonia and the patient was admitted to the hospital (Figure 1A). Her laboratory finding were: C-reactive protein (CRP) $500 \mathrm{ng} / \mathrm{dl}$ (normal range $<5 \mathrm{ng} / \mathrm{dl}$ ), presepsin (P-SEP) $780 \mathrm{pg} / \mathrm{mL}$ (reference values 55-184 pg/mL), leucocytes number $24 \times 10^{9}$ cells/liter, with $95 \%$ of neutrophils and normocytic anemia. Biochemical analysis were within normal range. She has initially been treated with antibiotic therapy Ceftriaxone $2 \mathrm{~g}$ intravenously and ciprofloxacin $1 \mathrm{~g}$ intravenously. Cultures of urine, blood and sputum were all sterile, although repeated for several times. The patient body temperature remained high- up to 40 degrees. Clinical pharmacologist was consulted on the third day, suggesting administration of Vancomycin $2 \mathrm{~g}$ per day intravenously, Metronidazole $500 \mathrm{mg}$ three times a day and Amikacin $2 \mathrm{~g}$ intravenously daily (Figure 1B). Three day after, chest $\mathrm{X}$ ray was repeated, showing no regression of inflammation (Figure 1C). Despite antibiotics treatment, the patient was constantly febrile, with slow inflammatory markers regression: $350 \mathrm{ng} / \mathrm{dl}$ CRP and Le $11 \times 10^{9}$ cells/liter, accounting for neutrophils in $85,5 \%$. Bronchoscopy was performed showing much mucus and pus. Material obtain using bronchoscopy was sent to laboratory for analyses. Arrived cultures for sterile. Infectologist was called in consultation, suggesting Levofloxacin $750 \mathrm{mg}$ daily intravenously with cessation of antipsychotic drugs, which brought the patient's fever down to 38 degrees. We empirically administered 2 millions units of Colistin three times a day intravenously, reaching the normal body temperature for the first time on the third day of treatment (Figure 1D, E). Inflammatory markers decreased as well: $70 \mathrm{ng} / \mathrm{dl}$ of CRP, presepsin 100 and leucocytes 7,8 with $72 \%$ of neutrophils. After 10 days of Colistin application, the patient was discharged. Since she was in psychiatric remission for a long time, her psychiatrist has decided to reduce her regular antipsychotic drugs dosage for a month due to pneumonia recovery. The patient came back for a regular check-up after a month and herchest X-ray showed regression (Figure F). She continued taking her psychiatric drugs in reduced dose. After three weeks CT scan was performed showing complete regression of inflammatory changes (Figure G). Psychiatrist switched her therapy to clozapine. After three months, she came to pulmonology check up because she was afraid to acquired pneumonia again. She felt well with one antipsychotic drug and her physical examination was within normal range, as well as chest X-ray.

\section{DISCUSSION AND CONCLUSION}

Here, we have presented a case of antipsychotic drugs-induced severe pneumonia in a patient with schizophrenia who was treated with one antipsychotic drugs for 15 years, but due to new symptoms psychiatrist changed her therapy into four drugs. Until antipsychotic agents were excluded, the patient was continuously febrile. Although discontinuation of APs drugs is frequently associated with exacerbation of 
psychotic symptoms in clinical practice, that was not the case with our patient, preserving his previous mental state, functional state and quality of life. However, consultation of an experienced psychiatric should be recommended in those situations in order to avoid the ceased-therapy caused adverse events, out of which suicide could be the most serious one. Therefore, it would be essential to have a written expert opinion about down-titrating or cessation of psychiatric therapy in those cases signed by an experienced psychiatrist.

The biological pathways underlying antipsychotic-induced pneumonia are not fully understood, although several plausible hypotheses have been postulated (3). Further understanding of drugs that are associated with higher risk of pneumonia and application of this knowledge in practice would enable prescription of non-pneumonia risk drugs in patients with predisposition risks for infectious respiratory diseases, such are: bedridden state, chronic respiratory diseases and/or sedative drugs usage. Observational data studies suggest a different safety profile for individual antipsychotics (AP) by class $(4,5)$. The review from the literature has identified several biological mechanisms that could lead to pneumonia accompanied by AP use. Pharmacology data in vitro have confirmed receptor affinities identified in the literature. Two targets, thromboxane A2 receptor (TBXA2R) and platelet activating factor receptor (PTAFR) were found to be the novel AP target receptors, potentially associated with pneumonia.

Biological pathways constructed using Cytoscape have identified biological links that could lead to pneumonia: downstream of TBXA2R and PTAFR innovative approaches for biological substantiation of drug-adverse event associations may strengthen evidence on drug safety profiles and help tailoring pharmacological therapies (5).

Complete Declarations:

- Ethics approval: The protocol of the study was approved by Medical School, University of Belgrade. All procedures were performed in accordance with the Declaration of Helsinki.

- Every patient who was admitted to our hospital had previously given written consent that his/her data could be used in scientific purposes and that their results could be published but not using their names or anything which could reveal their identity.

\section{DECLARATION OF INTEREST}

The authors declare that there are no conflicts of interests.

\section{Licensing}

This work is licensed under a Creative Commons Attribution 4.0 International (CC BY 4.0) License.

\title{
Sažetak
}

\section{TEŠKA PNEUMONIJA IZAZVANA ANTIPSIHOTIČNIM LEKOVIMA - ŠTA NE ODGOVARA, PACIJENT ILI LEK?}

\author{
Lazovic Biljana, ${ }^{1}$ Blazic Ivana, ${ }^{1}$ Zlatkovic-Svenda Mirjana, ${ }^{2,4}$ Zugic Vladimir ${ }^{3,4}$ \\ ${ }^{1}$ University clinical center "Zemun”, Belgrade, Serbia \\ ${ }^{2}$ Institute of rheumatology, University of Belgrade, Belgrade, Serbia \\ ${ }^{3}$ Clinic for lung diseases, Clinical center of Serbia, Belgrade, Serbia \\ ${ }^{4}$ School of medicine, University of Belgrade, Serbia
}

Uvod: Antipsihotični lekovi se načelno dele na tipične antipsihotike (ponekad se na njih odnosi termin „konvencionalni“ ili ,antipsihotici prve generacije“ ili neuroleptici) i na atipične antipsihotike; obe grupe su pogodne za lečenje akutne i hronične psihoze (na primer shizofrenija), manije, agitacije i drugih psihijatrijskih poremećaja. 2005. godine Američko udruženje za hranu i lekove je izdalo upozorenje o povećanom riziku opšte stope mortaliteta udružene sa atipičnim antipshoticima koji se koriste u starijoj populaciji pri lečenju demencije. Nebolnička pneumonija (CAP) bila je jedna od najčešće navođeniih uzroka smrti. Isto upozorenje bilo je prošireno i uključivalo je tipične antipsihotike 2008. godine, koje je sada uključivalo i ljude sa ili bez demencije.

Prikaz slučaja: Predstavljamo 65-godišnju že$\mathrm{nu}$, bele rase, koja je hospitalizovana zbog masivne pneumonije. Ona je bolovala od shizofrenije unazad 15 godina i u momentu prijema u bolnicu bila je u remisiji. Imala je konstantnu temperaturu od 40 stepeni Celzijuseve skale. Sve učinjene mikrobiološke analize bile su negativne (hemokultura, sputum, urino kultura, bris aspiriranog sadržaja uzetog kateterom). Bila je lečena različitim antibioticima bez napretka. Nakon promene antipsihotičnih lekova, pacijentkinja je pokazala spori napredak do potpunog ozdravljenja koje je usledilo nakon 3 meseca od početka terapije.

Diskusija i zaključak: Pneumonija povezana sa antipsihoticima je zapravo klinički vrlo značajan problem kod starih pacijenata, koji je zapažen u nekoliko epidemioloških studija. Ne postoji jasan dokaz koji govori u prilog postojanju povišenog rizika od pneumo- 
nije kod mlađih pacijenata koji su lečeni antipsihoticima. U populaciji starih, povećan rizik je dozno-zavisan i više je naglašena u ranijim fazama bolesti. Dalje studije treba da bolje definišu mehanizme koji se nalaze u osnovi pneumonije koju indukuju antipsihotici i koji

\section{REFERENCES}

1. Trifirb G, Spina E, Gambassi G. Use of antipsychotics in elderly patients with dementia: do atypical and conventional agents have a similar safety profile? Pharmacol Res. 2009; 59(1): $1-12$.

2. Knol W, Marum RJ, Jansen PA, Souverein PC, Schobben AF, Egberts AC. Antipsychotic drug use and risk of pneumonia in elderly people. J Am Geriatr Soc. 2008; 56(4): 661-6.

3. Gambassi G., Sultana J. Trifiro G. Antipsychotic use in elderly patients and the risk of pneumonia. Expert Opin Drug Saf. $2015 ; 14(1): 1-6$.

4. Huybrechts KF, Schneeweiss S, Gerhard T, Olfson M, Avorn J, Levin R et al., Comparative safety of antipsychotic medications in nursing home residents. J Am Geriatr Soc. 2012; 60(3): 420-9.

\author{
Correspondence to/Autor za korespondenciju \\ Biljana Lazovic \\ University clinical center „Zemun“, Belgrade, Serbia \\ Vukova 9, Zemun, 11070 Belgrade \\ phone +38162212040 \\ Fax +3812141569 \\ lazovic.biljana@gmail.com
}

treba da identifikuju podtipove korisnika antipsihotičnih lekova, koji su u povećanom riziku od razvoja pneumonije.

Ključne reči: antipsihotični lekovi, shizofrenija, pneumonija, toksičnost lekovima.

5. Rafaniello C, Lombardo F, Ferrajolo C, Sportiello L, Parretta E, Formica R et al., Predictors of mortality in atypical antipsychotic-treated community-dwelling elderly patients with behavioural and psychological symptoms of dementia: a prospective population-based cohort study from Italy. Eur J Clin Pharmacol. 2014; 70(2): 187-95.

6. Bauer-Mehren A., van Mullingen EM, Avillach P, Carrascosa Mdel C, Garcia-Serna R, PiZero J et al. Automatic filtering and substantiation of drug safety signals. PLoS Comput Biol. 2012; 8(4): p. e1002457.

7. Garcia-Serna R., Vidal D, Remez N, Mestres J. Large-Scale predictive drug safety: from structural alerts to biological mechanisms. Chem Res Toxicol. 2015; 28(10): 1875-87.

8. Gaulton A, Bellis Lj, Bento AP, Chambers J, Davies M, Hersey A, et al. ChEMBL: a large-scale bioactivity database for drug discovery. Nucleic Acids Res. 2012; 40 (Database issue): D1100-7. 